\title{
NARRATIVE DESIGNS IN ARTWORKS FROM BURMA/ MYANMAR IN THE NÁPRSTEK MUSEUM COLLECTIONS
}

\author{
Fiona Kerlogue - Dagmar Pospíssilová1
}

\begin{abstract}
This article gives an overview of material from Burma/Myanmar in the collections of the Náprstek Museum, with a focus on three types: lacquerware, silverware, and embroidery. Examples from the collection are linked by their use of narrative scenes as devices to embellish the surfaces, especially scenes from the life of the Buddha and scenes from the stories of his previous lives. Historical scenes are often depicted on lacquerware from Bagan. Techniques employed to decorate the objects are very much the same today as they were when the majority of the items discussed were made, that is in the $19^{\text {th }}$ century.
\end{abstract}

KEYWORDS: Burma/Myanmar - Náprstek Museum collections - arts and crafts silverwork - lacquerware - tapestry embroidery/kalaga

The Burmese ${ }^{2}$ collection of the Náprstek Museum contains around five hundred items in a range of types and materials. They include sculptures in metal, sandstone, marble, and wood. Figural wood carving is represented by small statues of the seated Buddha, and of nats and demons, some coated with gold lacquer and some decorated with tiny spangles and coloured glass beads. Painted figures of dancers, monks and courtiers are also included in the museum collection. The art of metal casting is represented by weights in the shapes of animals, bells, as well as weapons, exemplified by the dha (sword). The collection also contains a few examples of clothing and textiles, toys and marionettes representing popular characters from the traditional theatre. Most of the five hundred items originate from the $18^{\text {th }}$ to the $20^{\text {th }}$ centuries. Only a few of the Buddhist sculptures and votive plaques can be dated to earlier periods: late Bagan and Inwa. This article focusses on three of the decorative arts, linked by their elaborate and distinctive decorations, which reflect the importance of Buddhism, narrative, and cosmology in Burmese culture.

The Burmese collection of the Náprstek Museum was built up gradually from the time of Vojtěch Náprstek, the founder of the Museum, through purchases and gifts from Náprstek family friends. The earliest acquisitions came from physician and

1 Contacts: Fiona Kerlogue, School of Oriental and African Studies, University of London, UK; e-mail: fk17@soas.ac.uk; Dagmar Pospíśilová, National Museum - Náprstek Museum of Asian, African and American Cultures, Prague, Czech Republic; e-mail: dagmar.pospisilova@nm.cz. This work was financially supported by the Ministry of Culture of the Czech Republic (DKRVO 2019-2023/19.I.b, National Museum, 00023272).

2 The country formerly known as 'Burma' was renamed 'Union of Myanmar' in 1989 and later 'Republic of the Union of Myanmar'. The authors have retained the terms 'Burma' and 'Burmese' since the material under discussion and the sources consulted were almost exclusively created prior to the name change.

This work is licensed under the Creative Commons Attribution-Noncommercial-No Devivs 3.0 License 
traveller Jan Vilém Helfer (1810-1840)3 ${ }^{3}$, who brought small marble statues of Buddha and terracotta votive plaques from Burma, probably originating in a Buddhist cave in the Mawlamyine area. ${ }^{4}$ The collection was enlarged by Indologists Otokar Pertold (18841965) and Miloslav Krása (1920-2005). They enriched the collection with lacquer boxes and wood carvings but also with toy puppets of the main characters of the traditional theatre. In the 1960s the Burmese collection was substantially extended by the addition of a large number of various items gathered by Jiří Skřivánek (his biographic dates are unknown) during his employment in Burma. He collected Buddhist sculptures, lacquer boxes, wood carvings, glazed and plain pottery, as well as objects of an ethnographic character. In 2010 the museum received a gift of ten contemporary puppets. The most recent acquisition is a gift of five rare Chin textiles given to the museum by a couple of collectors from Myanmar. The growth of the collection has not been systematic, nor has it been centred around the colonial presence, as in some British museums ${ }^{5}$, or missionary activity, as in some American ones ${ }^{6}$. Nevertheless, it can offer users of the museum insights into the rich artistic and cultural traditions of a country still relatively unknown to users of European museums.

One of the most common features of the arts and crafts of Burma is the depiction of stories, through which Buddhist precepts and other moral lessons have been transmitted in material form from generation to generation over the centuries. They are depicted in a range of forms, as embellishments on the surface of objects or as objects themselves, as in the marionettes with which stories were performed at court and at religious and folk festivals. These stories include the epic Ramayana, stories of local guardian spirits, or nats, and most importantly the stories of the previous lives of the historical Buddha. These jātaka stories, in Naomi Appleton's definition, recount birth stories of the Bodhisatta (the Buddha-to-be) as told by the Buddha. ${ }^{7}$ They are learned from monks and monastic schools, from folk art and drama. They provide a basis for a whole range of ideas about virtue and about how people should behave in a social context. As Juliane Schober puts it, jātaka tales:

offer abundant material for religious education. Central motifs in the biographies of the Buddha elucidate moral principles, values, and ethics, and certain wellknown jätaka tales serve a didactic purpose in teaching younger generations about the tradition. Jätakas are salient across Buddhist communities and the themes they recount readily resonate with other aspects of religious knowledge and practice. As such, recounting certain jätaka stories in public sermons or even representing them in paintings can serve as commentary on current social and political issues. ${ }^{8}$

3 Jan Vilém Helfer was the first Czech citizen to reach Burma in the service of the British East India Company. They charged him to explore the natural resources in what was then known as Further India. He was successful but his life finished prematurely. His adventurous life was described in an account by his wife Pauline Helfer, who later married a nobleman named Nostitz: see Nostitz 1873; Nostitz 1878.

4 For valuable information on Helfer's collection we would like to thank Dr. Aye Aye Thin, Director of the National Museum in Naypyidaw, Myanmar.

5 See Dudley 1996; Green 2015.

6 See Fraser-Lu and Stadtner 2015, p. 8; Green 2008.

7 Appleton 2010.

8 See Schober 2003, p. 46. 
Lessons from history, especially relating to the establishment of Buddhism, are also important. Bagan's role in Burmese history is reflected in the proliferation of depictions of scenes from chronicles and relating to the early kings. Folk stories also provide subject matter for decorative motifs. One popular narrative centres on the age-old struggle between the Galon, or Garuda, against its arch-enemy the Naga, or serpent. The Galon, with its supernatural power and ability to counter the poison of the serpent, was a powerful symbol. In the first half of the $20^{\text {th }}$ century in Burma, Saya San, the leader of the rebellion of 19301931, was proclaimed Thupanakkan Galon Raja, the Garuda King. The Galon became the symbol of resistance to the rule of the British, who were symbolised by the Naga. ${ }^{9}$

\section{Silver}

Silverwork was one of the crafts at which Burmese artisans excelled in the $19^{\text {th }}$ and early $20^{\text {th }}$ centuries. Before the mid- $19^{\text {th }}$ century sumptuary laws had restricted the use of gold and silver vessels to those of royal blood; the palace and members of the court were the patrons of silversmiths. However, during King Mindon's reign (1853-1878), Lower Burma was annexed by the British, and the rules were relaxed. The manufacture of bowls of this type increased during the period which followed, partly as a result of demand from the British, who replaced the nobility as patrons.

There are five silver bowls from the second half of the $19^{\text {th }}$ century in the Naprstek collections. Of the two larger bowls, ngway-bala, one [Pl. 1] is inscribed with the name Ma Shwee Thee, probably the name of the maker, or possibly the owner, on the underside. The date of manufacture, $26^{\text {th }}$ October 1868 , and the weight of silver are engraved alongside. Like several other makers of this period, this one had a peacock as his trademark, probably a reference to the Konbaung dynasty (1752-1885), whose emblem was the peacock. ${ }^{10}$

Like other silver items from this period, bowls were made by first melting and then beating the silver into the desired shape. A composition of brick dust, oil and resin was then poured into the bowl. The design was marked out with a graver, and then the entire pattern engraved, following which the parts to be lowered would be punched in. This forced out those parts intended to be in relief. The resin composition was then melted out. Any punching required from the inside (repoussé) followed. There would have been much repetition of these steps before the bowl was ready for finishing, for which the bowl was filled again with a resin composition, and the surface chased and carved to add the texture and fine details characteristic of Burmese work. The bowl would finally have been heated and boiled in an alum solution, then brushed with soapnuts and cold water. The details would be burnished with wire brushes and the flat surfaces rubbed with enamel beads. ${ }^{11}$ The same methods of manufacture can be seen today in the silver workshops of Sagaing, north of Mandalay [Pls. 2-5].

This bowl is decorated around the circumference with figures showing the battle between the Naga and Galon. Also depicted is a bilu, or ogre, and biluma, an ogress, who may represent the mother of the nagas, Kadru, whose rivalry with Vinata, her sister and co-wife, and the mother of the birds, was the root cause of the conflict. Each figure is set between flat polished cusped arches, the space between the figures and below

9 Solomon 1969, p. 213.

10 Green 2008, p. 182.

11 See Tilly 1902 for a description of the silversmithing process in Burma at the turn of the $19^{\text {th }}$ and $20^{\text {th }}$ centuries. 
the decorative bands around the rim containing foliate motifs. Behind the figures the background space is filled with cross-hatching. Around the base are bands of stylised lotus leaves, partially echoed at the rim. The style of decoration suggests that the bowl was made in Mandalay. ${ }^{12}$ This silver bowl was probably part of the property transferred from the Mnichovo Hradiště castle, which was nationalized after the Second World War. The list of items transferred from there in 1948 includes several silver vessels, though it is very difficult to identify any one item from the list precisely because there are no detailed descriptions.

A smaller, finely made bowl [Pl. 6], probably also by a Mandalay silversmith, and probably also from the Mnichovo Hradiště castle, is decorated around the circumference with the twelve signs of the Burmese zodiac, each set into a 'house'. The first sign is Meiktha, the Ram, which corresponds with the Western astrological sign Aries, relating to Tagu (April), with which the Burmese year begins. This is followed by Pyeikthat, the bull, for Kason (May); Meidon, a composite figure of twins, said to symbolise male and female procreative powers in union, for Nayon (June) and then Karaka, the crab, for Wazo (July). Wagaung (August) is the month associated with Thein, the lion, and Tawthalin (September) with Kan, the virgin. A representation of a figure holding scales, Tu, is the sign for Thadingyut (October), with the scorpion, Byeiksa, for Tazaungom (November). For Nadaw (December), the archer, Danu, is shown holding a bow across his shoulders and an arrow in his hand. The next month is Pyatho, January, for which the sign is the Makara, a mythical sea creature depicted here with the head of an elephant and a fish tail, diverging from the Western sign for this month, Capricorn. The sign for Tabodwe, February, also differs from the western symbol of Aquarius, the water carrier. In Myanmar the month is represented just by Kon, the water pot. A symbol of three fishes, Mein, one above the other, stands for the last month of the year, Tabaung (March). Each sign is set within a stepped cross, a type of cartouche typical on silver and lacquer. An elaborate engraved motif on the underside has an animal figure at the centre, perhaps a hare. ${ }^{13}$

Astrology has a long history in Burmese culture. The relative positions of the heavenly bodies at the time of a person's birth are believed to have a strong influence over him or her, and specialists may be consulted in order to identify auspicious days when planetary influence is benign for important events. As well as the signs of the zodiac detailed above, the days of the week and the points of the compass are also connected with the planets and with animal motifs, and are represented at pagodas by shrines situated at particular cardinal point in terms of the pagoda structure. People perform rituals according to the day of the week on which they were born, or even the time of their birth, which determine which planetary influences they fall under. ${ }^{14}$ The animals of the days of the week are frequently depicted on Burmese silver vessels, and on lacquerware. In the Burmese astrological system, there are not seven, but eight days in a week, each corresponding with a point on the compass, a planet, and an animal. Wednesday is divided into two, with the morning associated with the tuskless elephant, the afternoon with the tusked elephant. ${ }^{15}$

12 See Wilkinson et al. 2013, p. 80 for characteristics which can help to identify the origin of items of Burmese silverware.

13 The hare is both one of the emblems of the twelve-year cycle in Burma and one of the forms in which the Buddha-to-be appears in a popular jātaka tale.

Schober 1980. 
The silver collections at the Náprstek Museum are small compared with other national museum collections, but the few items we focus on here are fine examples, technically accomplished, and illustrate well both the style of late $19^{\text {th }} /$ early $20^{\text {th }}$ century Burmese silverwork, and those aspects of Burmese culture depicted in the decoration.

\section{Lacquerware}

Narrative scenes frequently appear in lacquerware. The Náprstek collections contain examples of three of the main types of decorative Burmese lacquerware: yun, in which the lacquer is engraved, usually in several colours; shwei-zawa, where the lacquer is covered with patterns in gold leaf; and relief-moulded work in which the raised decoration is formed of a lacquer paste, thayo. The thayo paste is formed of a mixture of boiled lacquer and cow dung, powdered bone or the ash of rice stems. The lacquer itself, thissi, or thitsi, is the sap of a tree (Gluta usitata, or Melanorrhoea usitata Wall), tapped in much the same way as rubber.

Engraved designs are achieved by a complicated process which may involve as many as five colours: red, black, green, yellow, and sometimes blue, the latter a late $20^{\text {th }}$ century development. Circular boxes decorated in this way have a base of coiled bamboo strips [Pl. 7], or woven bamboo and sometimes horsehair [Pl. 8]. The base is covered in several layers of a mixture of ash or sawdust and thitsi. After these layers of lacquer have been repeatedly applied, dried and smoothed, the surface is polished and then engraved [Pls. 9-10]. The engraved bowl is covered with a mixture of lacquer and a colouring agent, which is then wiped away from the surface where it has not been engraved. This process is repeated several times using different colours, producing a complex and colourful but harmonious design.

Three of the lacquer pieces decorated in yun technique in the Náprstek collections, all from the city of Bagan, carry inscriptions suggesting the nature of the narrative content. ${ }^{16}$ One cylindrical box for betel ingredients, kun-it [Pl. 11] is decorated with scenes captioned as 'King Kusa consulting'; 'U Dain Na dropping rock boxes' and 'King U Dain Na showing a shawl after arriving in the city'. ${ }^{17}$ Other inscriptions declare that this piece is fine lacquer ware for royalty, with 'five appearances' (i.e. colours), made in Hsaya Thet's workshop, ${ }^{18}$ Taik Su ward in the city of Bagan. A similar betel box of 'five appearances', has inscriptions indicating that it was made by medal-winner Hsaya Sein, in Yone Tan ward in Bagan [Pl. 12]. A further inscription declares that it is 'genuine and valuable'. The scene is of: 'King Kaorappa playing with cowrie shells'. A similar box, also 'with five appearances', was made in Hsaya Nyuint's workshop, Taik Su ward in the city of Bagan [Pl. 13]. These three pieces were donated to the Náprstek Museum in the 1960s by Otakar Pertold (1884-1965), who specialized in Indian Studies and who worked after the Second World War as the first Czechoslovak consul in Mumbai, India. During his service he collected in India, Sri Lanka, and Burma.

16 The authors are very grateful for the help provided by Aye Aye Thinn, the Director of the National Museum in Naypyitaw, in translating the inscriptions on the lacquer items.

17 This may be a reference to the Kusa-jātaka. Kusa, the ugly brother, finally wins the love of his wife princess Papawati. See Isaacs and Blurton 2000, p. 61. I have not been able to discover how King U Dain Na comes into the story.

18 'Hsaya' here is an honorific meaning 'teacher' (or 'master, craftsman'), commonly given in relation to a man of senior rank. 
Two lacquer pieces in the collection are of black lacquer decorated with gold leaf, in the shwei-zawa technique. On one of these, a vase [Pl. 14], the surface of the main body is embellished with swirls of chupan scrolling, a design characteristic for Burmese gold leaf lacquer. ${ }^{19}$ This main panel of patterning is set between further horizontal bands of scrolling and concentric lines above and below. The second piece is a shallow circular box, it [Pl. 15], decorated on the upper face of the lid with scenes from the Sama-jātaka, a complicated story of filial piety. The Sama-jātaka is one of the stories of the Buddha's previous lives and demonstrates the perfection of renunciation (nekkhamma), one of the ten virtues necessary to become a Buddha. It is a complex story in which many of those involved learn key lessons, though it is Suvanna Sama who is the Buddha-tobe. ${ }^{20}$ In the lower part three figures are depicted: on the left is Suvanna Sama, who as a Bodhisatta has chosen to be reborn on earth in order to help his parents to attain a better rebirth themselves. He is carrying a pot in which he is fetching water from the river for his parents. In the centre is his father Dukulaka and to the right his mother Parika, ascetics who have both been blinded at an earlier stage of the story and are thus desperately poor. Continuing in an anti-clockwise direction King Piliyakkha is depicted out hunting, carrying his bow. He has seen the golden-skinned Sama and thinking that he is either a deity or a naga, he decides to shoot him in order to discover which is the case. A celestial being, Devi Bahusundari, remonstrates with the king. In the story the dying Sama does not condemn Piliyakkha, only lamenting what will become of his parents without him. Piliyakkha repents, and Sama, who is restored to life, tells the King the ten rules of Law which he must follow to reach the world of the immortals. Sama's parents, depicted on the left, regain their sight. The story is replete with examples of proper Buddhist behaviour: many learn lessons and are later reborn at higher levels; but the key moral element of the story is Sama's renunciation in order to help his parents. ${ }^{21}$

The shwei-zawa decoration of both of these pieces is achieved by painting the design on in a mixture of gum and orpiment. Gold leaf is applied to the surface. When the bowl is subsequently washed, the gum mixture is removed, leaving the design in black lines, while the gold leaf adheres to the rest of the surface. This technique was most connected with Pyay (Prome) in the $19^{\text {th }}$ century but is now undertaken in Bagan. ${ }^{22}$

The last of these three techniques is well illustrated in a large offering vessel [Pl. 16], hsun-ok, comprising a bowl and lid and an inner tray. The external decoration is made up of scrolls of thayo work in which the paste has been moulded and then inset with spangles, alternately red and white, within a circle of eight other spangles arranged in nawarat ('nine gems') style. ${ }^{23}$ This technique of moulded lacquer ornamentation was in the $19^{\text {th }}$ century associated with Mandalay. ${ }^{24}$ The central spire of the lid is topped with a figure of a sacred hintha bird. Elizabeth Moore has discussed how the significance of the hintha bird in Burmese Buddhist art is in part explained by the Javana-Hamsa-jātaka:

19 This piece was transferred to the Museum in 1949 from an unknown source. It had probably belonged to an individual who had worked in India in the 1930s.

20 See Cowell 1907, p. 38-52.

21 Spencer 1966; The bowl was purchased by the Museum from an antique shop in 1973.

22 Watt 1906, p. 143.

23 See Fraser-Lu 1994, p. 243, Fig. 235 for a comparable example with this motif.

24 Watt 1906, p. 144. 
After a long series of events the Lord Buddha was a king of the hinthas, who competed in a race against the sun. When the human king praised the bird's speed, the hintha replied that his swiftness was nothing compared to the passing of a human lifetime. The king, who was deeply afraid of death, fell unconscious to the ground. His people also became stricken with fear. Eventually the king sought instruction from the hintha. The bird counselled him not to be troubled, to practise the ten laws incumbent on kings, particularly charity.

Respect is paid to the wisdom of the hintha as a result, and it appears in the royal regalia as well as in pagoda compounds. ${ }^{25}$

Lacquer techniques are also used on four lacquered chests, sadaik, in the Náprstek collections. Such chests were used in monasteries for storing manuscripts. They are decorated by attaching relief-moulded figures to the surface with lacquer. Additional elements were made of strips of lacquer arranged in curvilinear designs applied to the surface. These decorations, often representing scenes from the life of the Buddha, or sometimes from one of his previous lives, are then covered with another layer of lacquer. The decorated sides would finally be gilded.

The design on the front panel of one finely lacquered and gilded chest [Pl. 17] depicts at the centre a stupa flanked by two guardian lions, or chinthe. A stupa would typically contain a relic associated with the Buddha. Above and to the right of the stupa, monks bend their heads in worship. On each side is a prayer post, or tagundaing. topped with the auspicious figure of a hintha. Tagundaing are erected in the precincts of Burmese pagodas to announce the triumph of Buddhism over local animistic spirits.

To either side of the tagundaing and below them are a bell and umbrella, also features of pagoda compounds. In large pagodas, an umbrella, or thi, is usually to be found at the top of the main stupa, its tip studded with precious stones. Thi also top the smaller stupas in the compound. On the main stupa thi were sometimes donated by kings and queens, sometimes of gold, and are often hung with bells, whose tinkling attracts heavenly beings. Larger bells are also found on pagoda terraces, where they are struck by visiting devotees to draw the attention of the spirits of the sky and earth to the visitors' prayers. Bells, both large and small, are donated to the pagoda, earning the donors religious merit. ${ }^{26}$

A lacquered Kammavaca manuscript in the collection, a text which sets out rules for ordination and other monastic ceremonies [Pl. 18], has leaves and wooden coverboards all lacquered in red and gilded. The coverboards are decorated with a row of linked circles and lozenges in thayo in relief, the outlines of the design accentuated with inlaid green and white spangles. The text, in Pali language and written in Burmese 'tamarind seed' script, fills both sides of each leaf with six lines in black lacquer on a red and gilt ground. The base is probably of palm leaf. The manuscript was bought by the Museum from Jiří Skřivánek in $1968 .{ }^{27}$

25 Moore 1995, p. 28.

26 Scott 1910, p. 202.

27 Dr. Jiří Skřivánek and his wife, Dr. Marie Skřivánková, worked in Burma in the second half of the 1960s. As an expert in the United Nations, Dr Jiří Skřivánek was affiliated with the Rangoon University in the Department of Physics. He was in personal contact with the then director of the Náprstek Museum, Dr. Erich Herold, who encouraged him to collect for the museum. On the basis of a limited correspondence it is clear that the director specified what kind of items the museum was interested in. The correspondence between 1966 and 1969 is focused on arrangements for the transport of the collection, which contained about three hundred items. 
Other lacquered items in the collection include carved stone and wooden figures, of the Buddha Sakyamuni, the historical Buddha, for example, some of which have been lacquered in red and then gilded and inlaid with spangles. The collection also contains more recent lacquer items using modern materials. Decoration of lacquered items in the Náprstek collection shows the use of historical narratives, especially in yun work from Bagan, as well as religious themes, particularly in gilded thayo lacquerware items associated with the practice of Buddhism and of making merit.

\section{Kalaga}

The distinctive sumptuous Burmese wall hangings known as kalaga are now produced chiefly for tourists, though they were once used to define space in and decorate the walls of palaces and the homes of the wealthy. They were also donated to monasteries. In the late $19^{\text {th }}$ century they were often used as backdrops against which group photographs were taken. It was in the $19^{\text {th }}$ century that velvet became the background fabric of choice, against which elaborate figurative scenes were created using applied and raised fabric elements, usually the main figures, with sequins, beads, semi-precious stones and other embellishments framing the scene and filling the rest of the space. The technique is known as shwe-gyi-do, or 'gold thread sewing'. Very little actual embroidery is involved; the chief use is to indicate facial features and similar details. The shwe-gyi-do method, which can create a rich visual effect with what are in fact relatively inexpensive materials, was also used for ceremonial animal trappings, garments, shoes and puppet costumes.

Religious themes, especially narrative scenes from the jātaka tales or from the Ramayana, were common in large kalaga wall hangings which might be several metres in width. Nowadays small rectangular pieces are more common, depicting a single figure such as a dancer or animal. The Náprstek Museum has several examples in its collections. Of these, three of the larger narrative pieces are inscribed with phrases explaining the scene depicted. ${ }^{28}$ In one example [Pl. 19], bought from an antique shop in 1987, the design is divided into three scenes, each from a different one of the last ten jātaka stories, the Mahanipata. These are the best known of the jātaka stories, illustrating the ten virtues, or paramita, which must be perfected in order to reach enlightenment.

The middle section shows a scene from the Mahosadha-jätaka, which illustrates the perfection of wisdom (panna). The clever sage Mahosadha saves the kingdom for King Mithila by making wise decisions in a series of difficult cases. The inscription reads: 'Mahosadha answers the question'.

The story illustrated on the right is from the Candakumara-jātaka, a story in which the king's priest advised him to make sacrifices, including those of other members of his family. Candakumara offered himself for sacrifice in order to save the others. However, the queen called upon the gods to help, and they prevented the ceremony from taking place. The scene shows the moment when Candakumara is about to be sacrificed, with the god Sakka hovering above. The inscription reads: 'Candakumara's throat bleeds'. This jätaka illustrates the perfection of generosity (dana). In this instance he has offered his own life, the highest form of virtue.

28 The authors are very grateful for the help of San San May, formerly of the British Library, for her help in translating the inscriptions on the kalaga. 
The scene on the left depicts Prince Vessantara, whose extreme generosity leads him to give away his two children to a Brahmin who wants them as slaves. The inscription reads: 'Vessantara gives away Ganha and Jali'. Alexandra Green has emphasised how popular this particular jātaka became as a reminder of the importance of giving:

In Burma, the importance of giving was and is evinced by the popularity of the Vessantara Jātaka, the last of the ten great jātaka stories and the tale associated with the virtue of generosity. Its increasingly exclusive presence as a representative of the jattaka stories in the wall paintings of the nineteenth century, and the frequency of its depiction in other media, such as manuscripts, wood carvings, and kalagas, embroidered and appliqued textile hangings, further instantiates its significance. This in turn reveals the primary relevance of the virtue (pāramī) of generosity within Burmese society and highlights it as a major vehicle for lay participation in religious activities. ${ }^{29}$

A second kalaga [Pl. 20], bought from a private individual in 1987, again depicts a scene from the Vessantara-jātaka, illustrating the generosity of Prince Vessantara. In this scene the prince gives away his magical white elephant, which had the power to bring rain to the country, to Brahmins whose lands were suffering from drought. The inscription is: 'giving away the elephant'.

While the depiction of jätaka stories on these kalaga might be taken to indicate that they were made for local use rather than for foreigners, such scenes were popular with both Burmese and foreigners. ${ }^{30}$ The attraction to foreigners of the distinctly Burmese iconographical repertoire, materials and techniques is almost certainly echoed in the other items considered in the article, demonstrating the way collectors are drawn to the novel, the curious, and the other.

\section{Conclusion}

This article has focussed on material in the Náprstek Museum Burmese collections in three media: silverwork, lacquerware, and embroidery. This particular material was chosen as none of the items had been previously catalogued or published, and the opportunity to have inscriptions translated and to consult expert sources, within Burma itself and in the literature, enabled the authors to interpret the decorative motifs. These three media were the focus of the authors' field work in centres of production in Myanmar in 2019, in which an understanding of the current techniques was gained; continuity of methods of manufacture became clear. Research of the iconography revealed the centrality of cosmological understandings, as evidenced in the silverwork, Buddhist teachings, especially as depicted in the kalaga, and narrative themes, as shown in all three media, in the art of Burma.

29 Green 2018, p. 8.

30 Fraser-Lu and Stadtner 2015, p. 72. 


\section{Literature:}

Appleton, N. (2010). Jataka Stories in Theravada Buddhism: Narrating the Bodhisatta Path. Burlington, VT: Ashgate.

Cowell, E., ed. (1907). The Jataka, or stories of the Buddha's Former Births, Vol. VI. Cambridge: Cambridge University Press.

Dudley, S. (1996). Burmese collections in the Pitt Rivers Museum: an introduction. Journal of Museum Ethnography, 5, pp. 57-64.

Fraser-Lu, S. (1982). Kalagas: Burmese Wall Hangings and Related Embroideries. Arts of Asia, 12(4), pp. 73-82.

Fraser-Lu, S. (1984). Sadaik: Burmese Manuscript Chests. Arts of Asia, 16(4), pp. 68-74.

Fraser-Lu, S. (1989). Silverware of South-East Asia. Singapore: Oxford University Press.

Fraser-Lu, S. (1994). Burmese Crafts. Past and Present. Kuala Lumpur: Oxford University Press.

Fraser-Lu, S. and Stadtner, D., eds. (2015). Buddhist Art of Myanmar. New Haven London: Asia Society Museum, Yale University Press.

Green, A., ed. (2008). Eclectic Collecting: Art from Burma in the Denison Museum. Singapore: NUS Press.

Green, A. (2015). From India to Independence: the formation of the Burma collection at the British Museum. Journal of the History of Collections, 28(3), pp. 449-463.

Green, A. (2018). Buddhist Visual Cultures, Rhetoric, and Narrative in Late Burmese Wall Paintings. Hong Kong: Hong Kong University Press.

Isaacs, R. and Blurton, T. (2000). Visions from the Golden Land: Burma and the Art of Lacquer. London: British Museum Press.

Moore, E. (1995). Flights of Fancy: Hintha and Kinnaya, the Avian Inspiration in Myanmar art. Oriental Art, 41(2), pp. 25-31.

Nostitz, P. (1873). Johann Wilhelm Helfers Reisen in Vorderasien und Indien, 2 Bände. Leipzig: Brockhaus.

Nostitz, P. (1878). Travels of doctor and madame Helfer: Syria, Mesopotamia, Burmah and other lands. Narrated by Pauline Countess Nostitz (formerly madame Helfer) and translated into English by Mrs. George Sturge. In two volumes. London: Richard Bentley and Son, New Burlington Street.

Schober, J. (1980). On Burmese Horoscopes. The South East Asian Review, 5(1), pp. 43-56.

Schober. J. (2003). Sacred Biography. In R. Buswell, ed., Encyclopaedia of Buddhism. New York: Macmillan.

Scott, J. (1910). The Burman His Life and Notions. $3^{\text {rd }}$ ed. London: Macmillan.

Solomon, R. (1969). Saya San and the Burmese Rebellion. Modern Asian Studies, 3(3), pp. 209-223. 
Spencer, R. (1966). Ethical Expression in a Burmese Jātaka. The Journal of American Folklore, 79(311), pp. 278-301.

Than Htun. (2013). Lacquerware Journeys. The Untold Story of Burmese Lacquer. Bangkok: River Book Co. Limited.

Tilly, H. (1902). The Silverwork of Burma. Rangoon: Superintendent of Government Printing.

Watt, G. (1906). Bulletin of Miscellaneous Information (Royal Botanic Gardens, Kew), 5, pp. 137-147.

Wilkinson, W., Wilkinson, M.-L. and Harding, B. (2013). Burmese Silver from the Colonial Period. Arts of Asia, 43(3), pp. 69-81. 


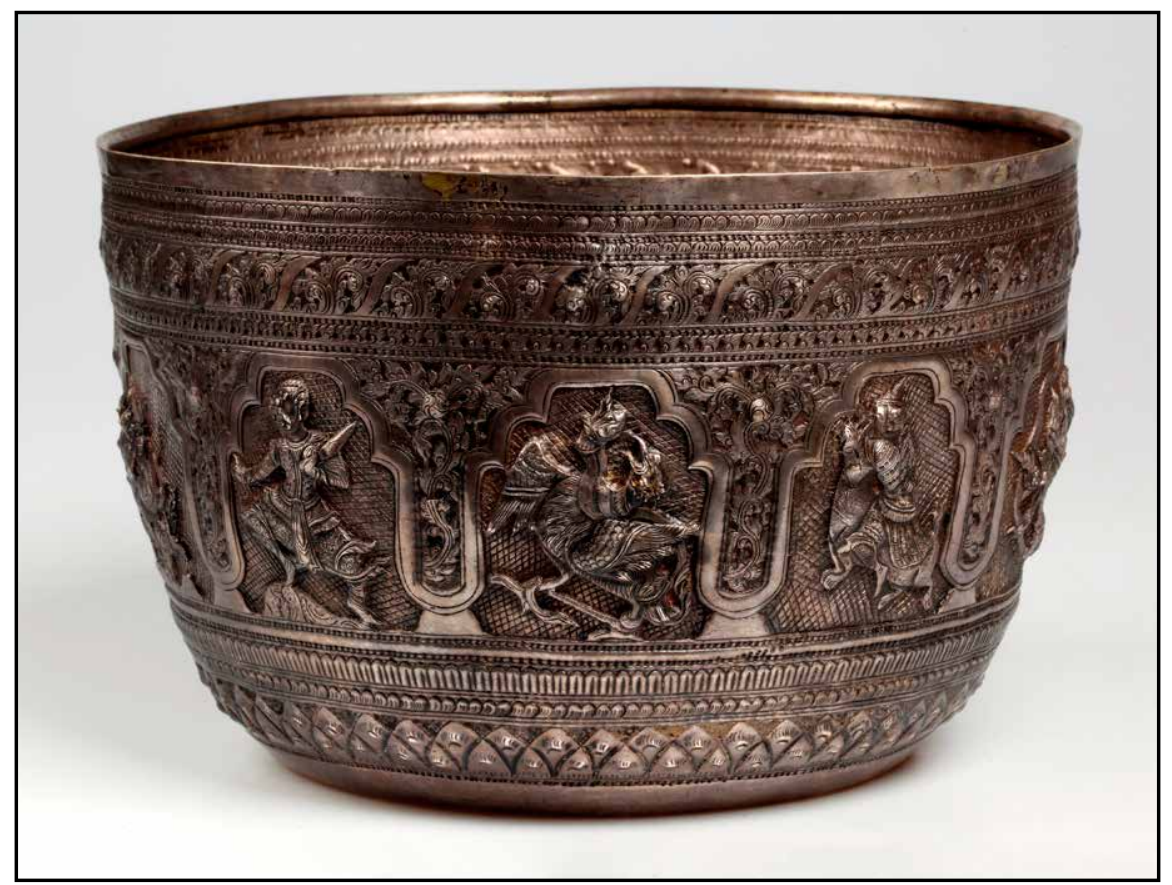

Pl. 1. Silver bowl, ngway-bala. Mandalay, 1868. Dimensions: h. $18.5 \mathrm{~cm}$, diameter $29 \mathrm{~cm}$. Transferred from the National Cultural Committee, 1948. Inv. No. 43562 (Photo: J. Vaněk, 2020).

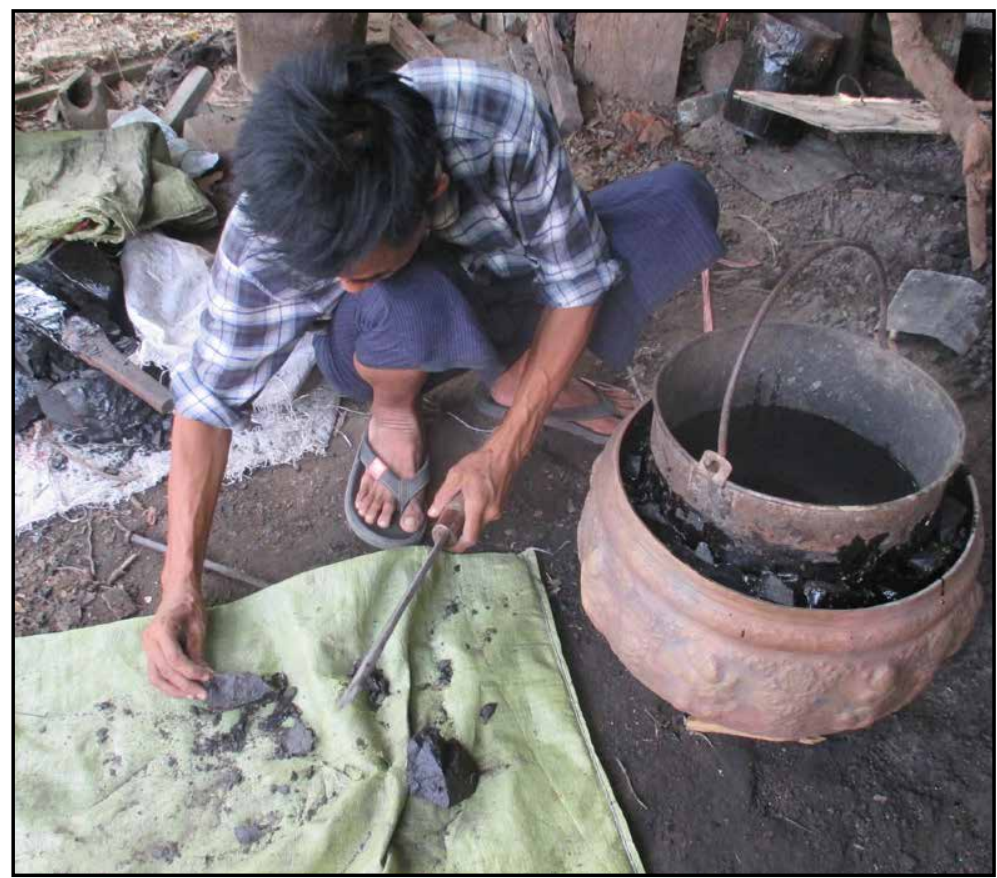

P1. 2. U Ba Mhin and Daw Khin Lay silversmithing workshop in Ywahtaung, Sagaing (Photo: F. Kerlogue and D. Pospíšilová, 2019). 


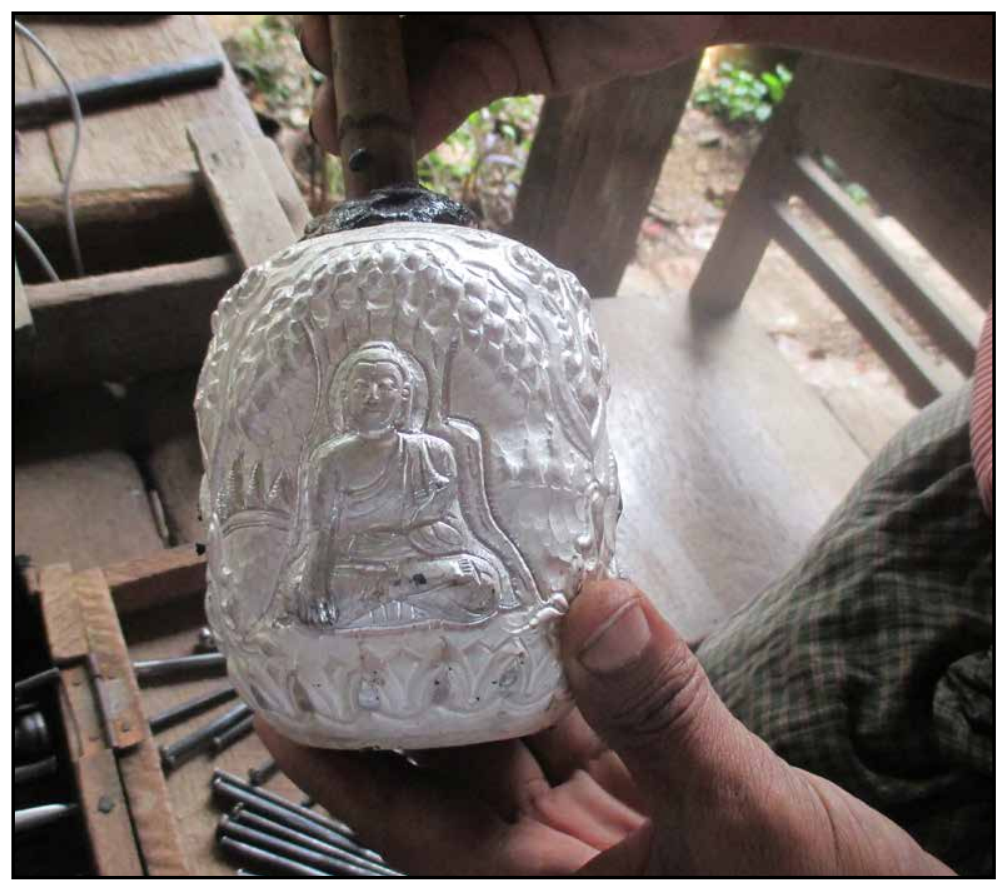

P1. 3. U Ba Mhin and Daw Khin Lay silversmithing workshop in Ywahtaung, Sagaing (Photo: F. Kerlogue and D. Pospíšilová, 2019).

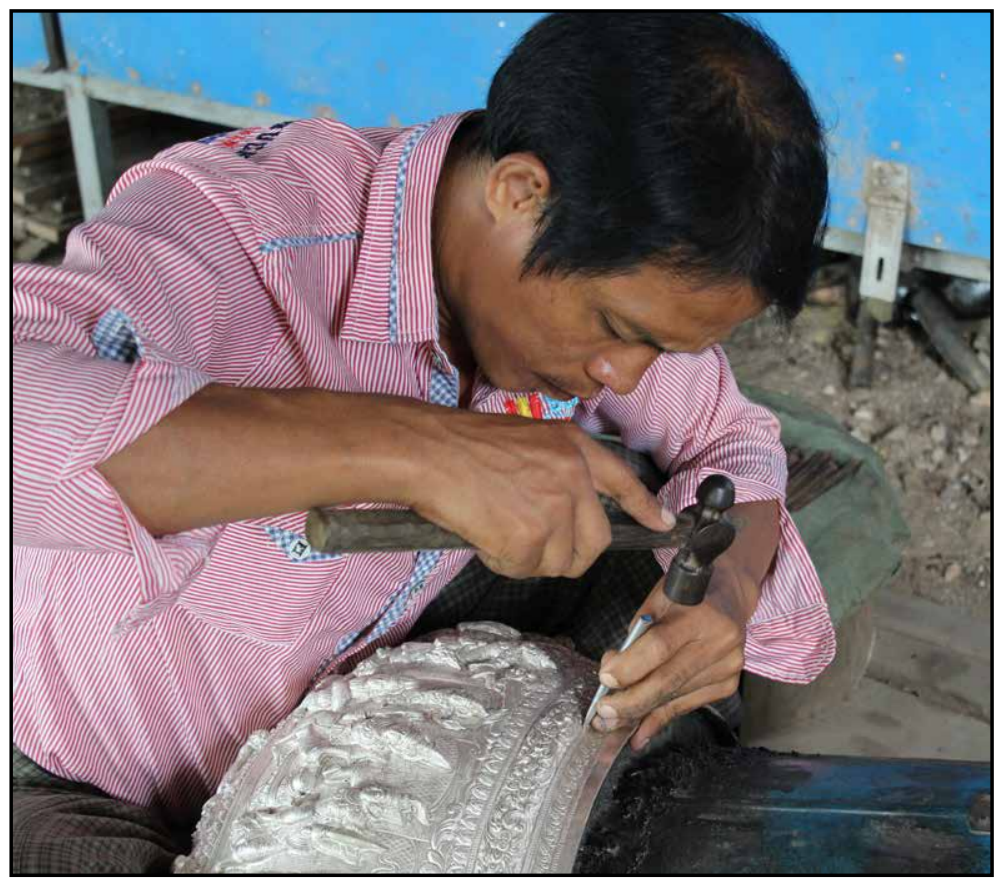

P1. 4. U Ba Mhin and Daw Khin Lay silversmithing workshop in Ywahtaung, Sagaing (Photo: F. Kerlogue and D. Pospíšilová, 2019). 


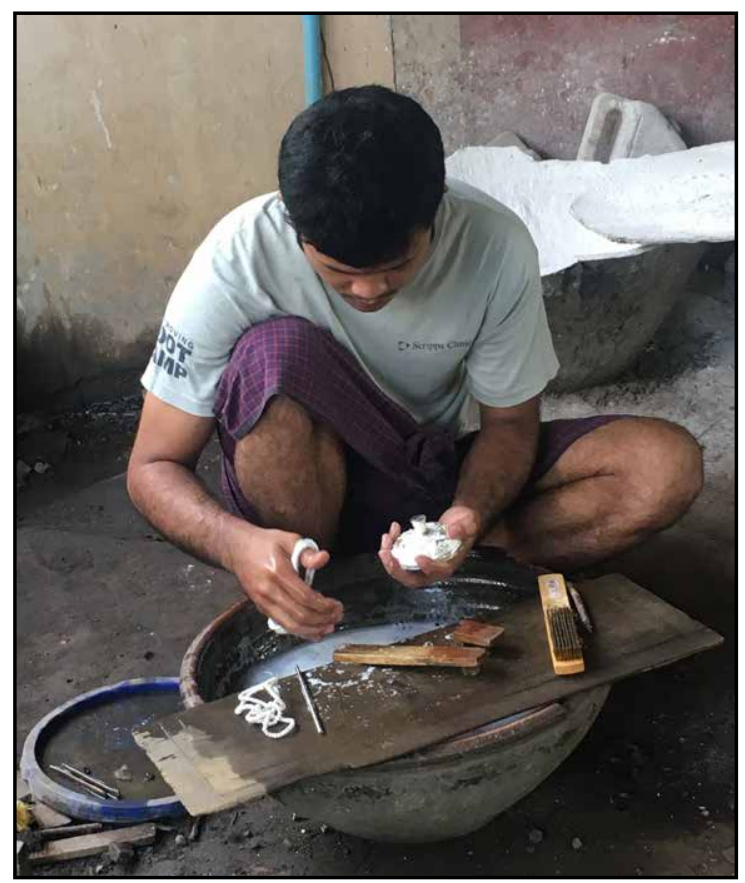

Pl. 5. U Ba Mhin and Daw Khin Lay silversmithing workshop in Ywahtaung, Sagaing (Photo: F. Kerlogue and D. Pospíšilová, 2019).

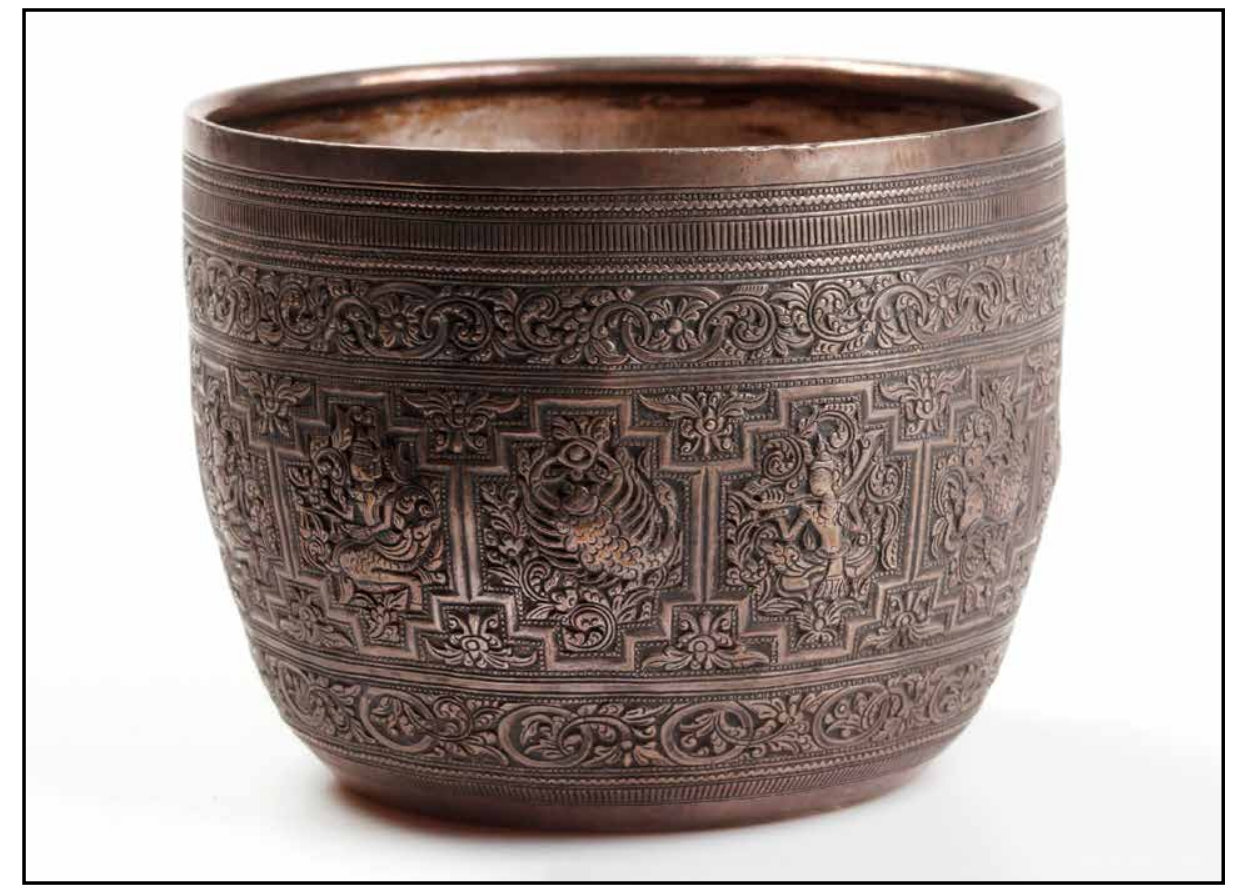

Pl. 6. Silver bowl, ngway-bala. Mandalay, probably 1860s. Dimensions: h. $8.6 \mathrm{~cm}$, diameter $11 \mathrm{~cm}$. Transfer from the National Cultural Committee, 1948. Inv. No 43434 (Photo: J. Vaněk, 2020). 


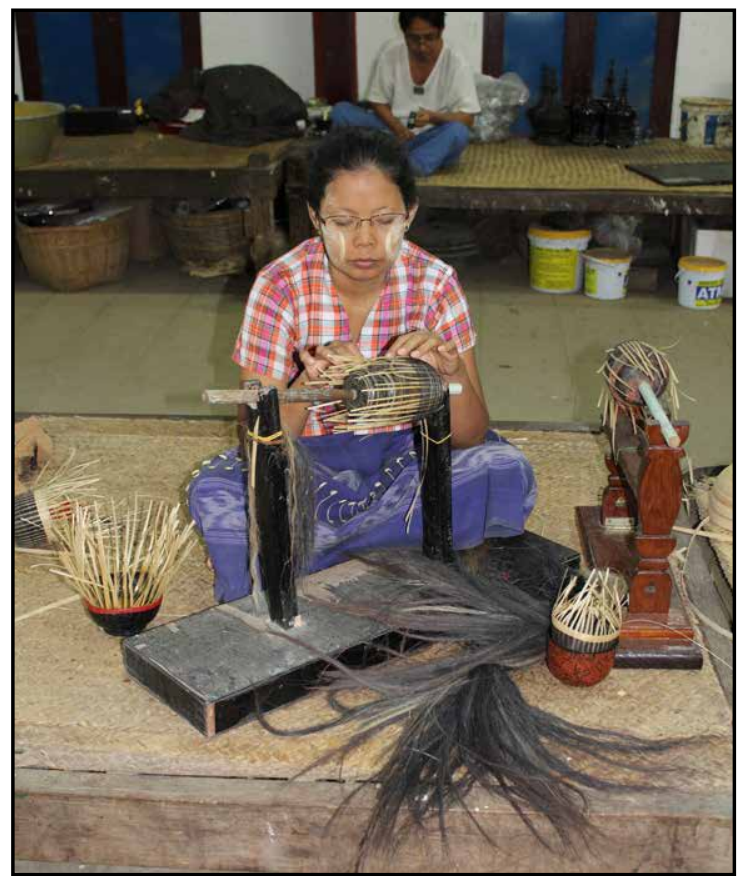

Pl. 7. Weaving the base of a small bowl on a spindle, using split bamboo and horsehair, before the lacquer is applied. Mya Thit Sar Lacquer Workshop (Photo: F. Kerlogue, 2019).

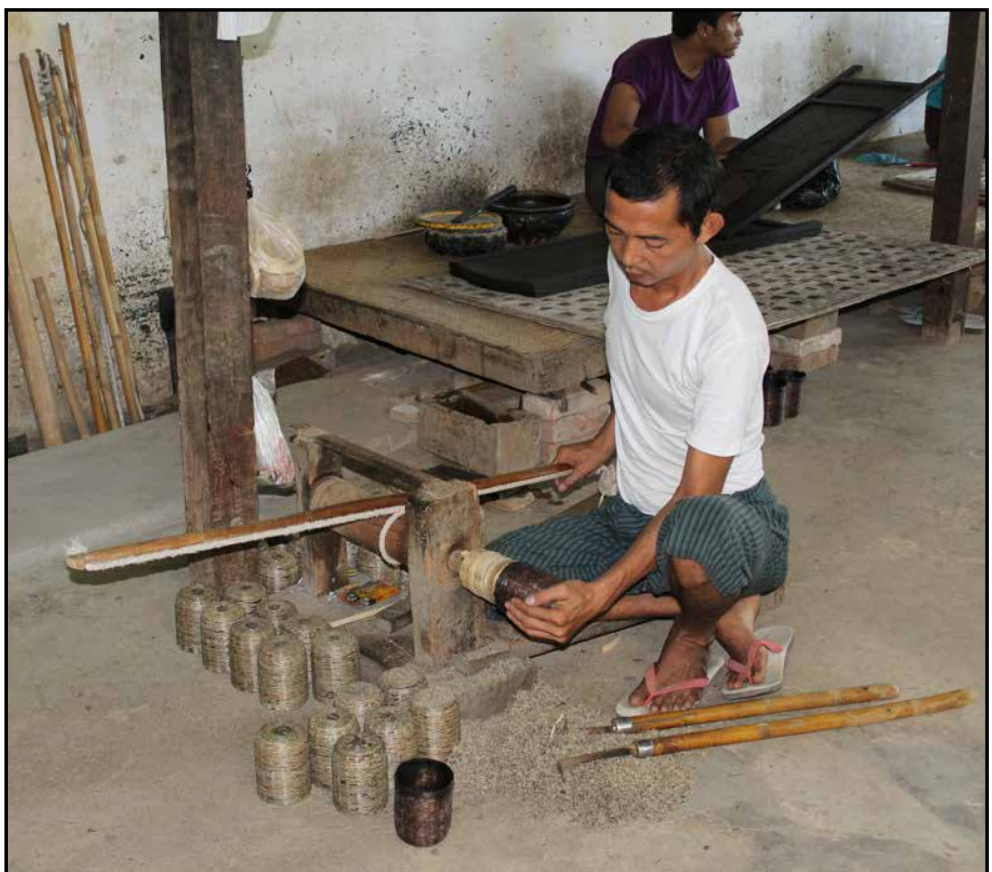

P1. 8. The surface of the woven base is made smooth on a lathe using a blade set in a wooden handle. Htun Lacquer Workshop, Bagan (Photo: F. Kerlogue, 2019). 


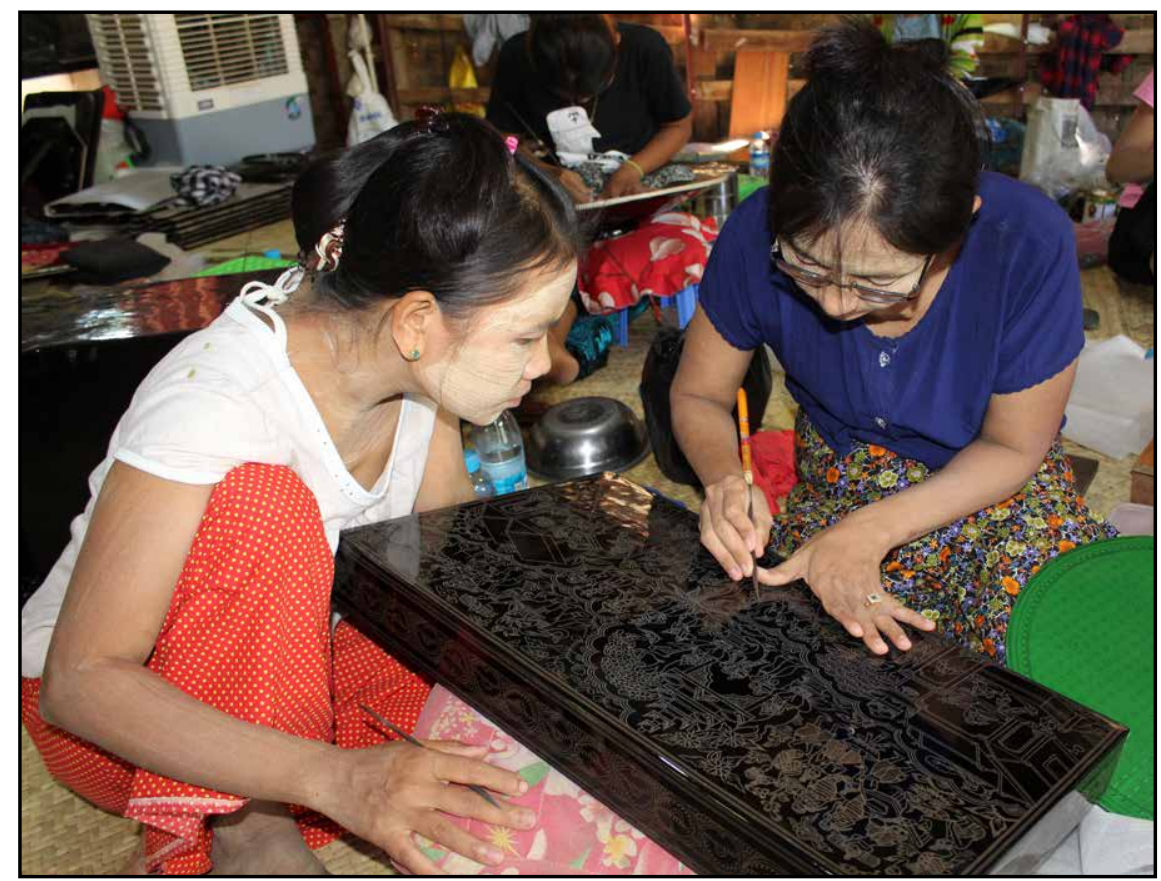

Pl. 9. A young worker is taught how to incise the design on the lacquered surface. Mya Thit Sar Lacquer Workshop, Bagan (Photo: F. Kerlogue, 2019).

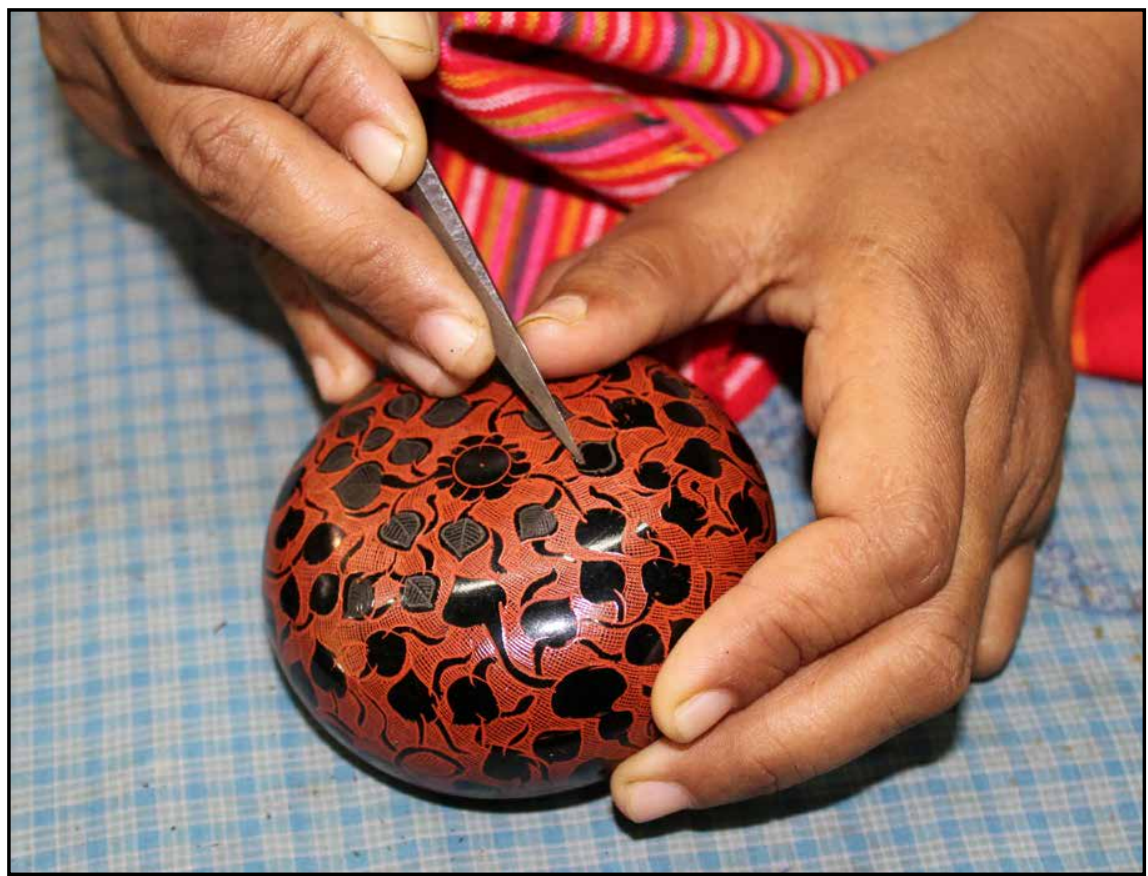

P1. 10. After the red colouring has been applied to the first incisions, new incisions are made. These will later be filled with the next colour. Htun Workshop, Bagan (Photo: F. Kerlogue, 2019). 


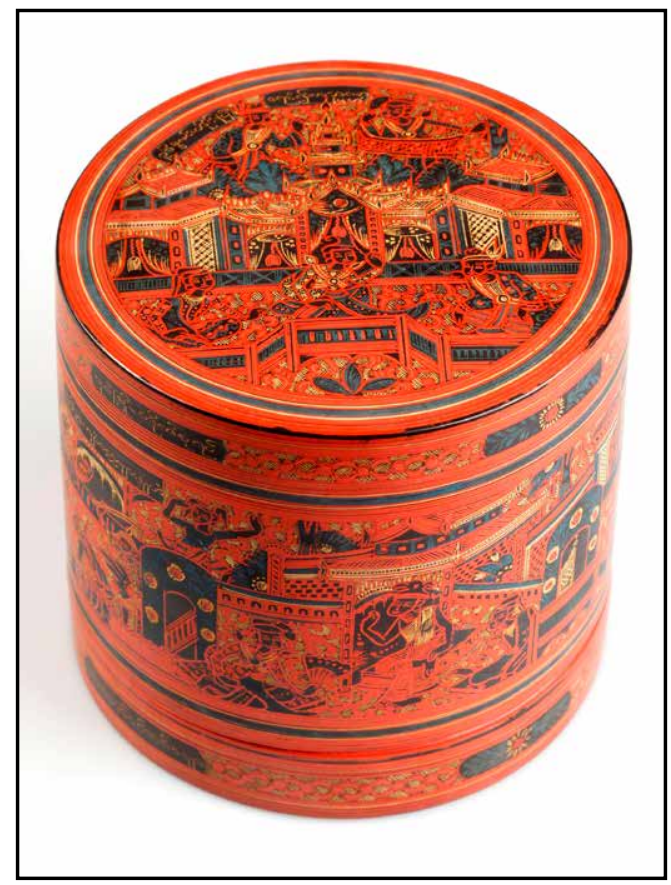

Pl. 11. Lacquer box, kun it. Bagan, 1960s. Dimensions: h. $12 \mathrm{~cm}$, diameter $12.6 \mathrm{~cm}$. Given by Otakar Pertold, 1962. Inv. No. A1177 (Photo: J. Vaněk, 2020).

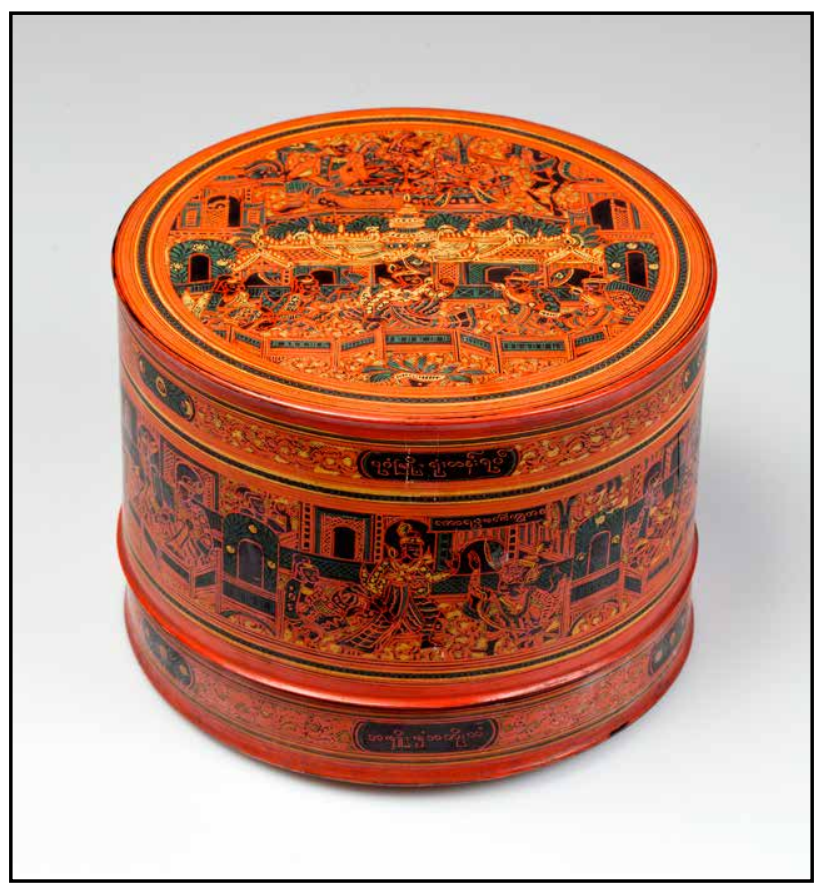

P1. 12. Lacquer box, kun it. Bagan, 1960s. Dimensions: h. $13.7 \mathrm{~cm}$, diameter $12.7 \mathrm{~cm}$. Given by Otakar Pertold, 1962. Inv. No. A1192 (Photo: J. Vaněk, 2020). 


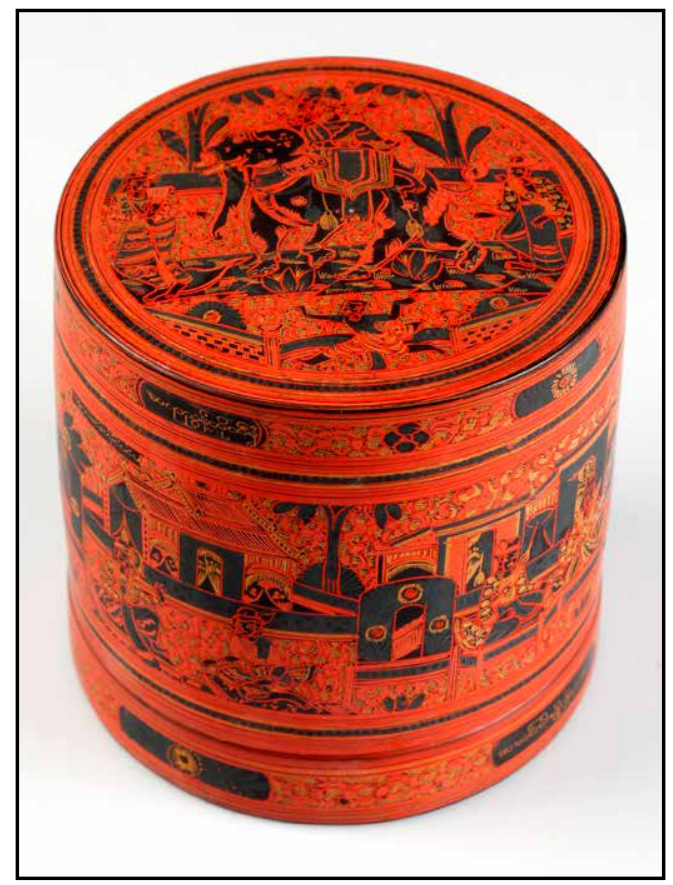

P1. 13. Lacquer box, kun it. Bagan, 1960s. Dimensions: h. $12.6 \mathrm{~cm}$, diameter $12.7 \mathrm{~cm}$. Given by Otakar Pertold, 1962. Inv. No. A1191 (Photo: J. Vaněk, 2020).

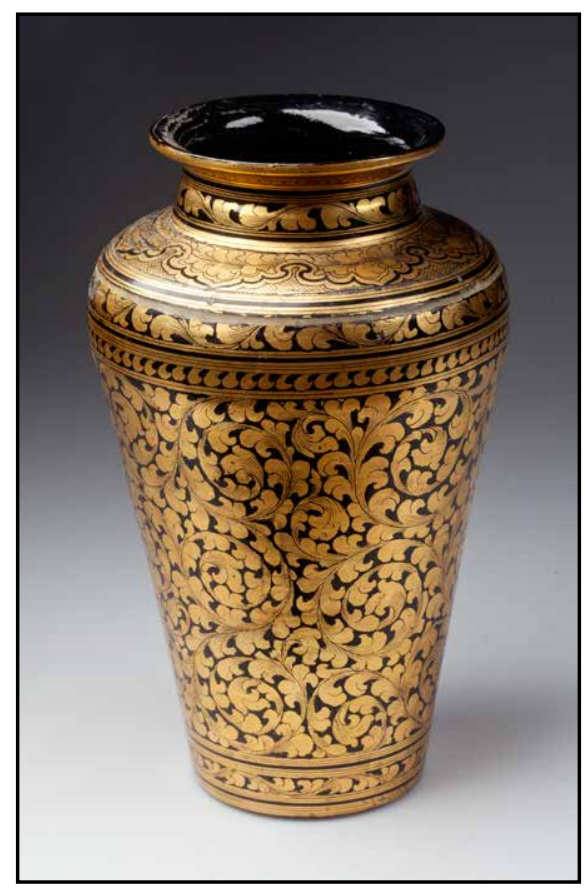

Pl. 14. Lacquer vase decorated with shwe-zawa. Bagan, probably early $20^{\text {th }}$ century.

Dimensions: h. 25.5 cm. Transferred to the Museum in 1949. Inv. No. 16309 (Photo: J. Vaněk, 2020). 


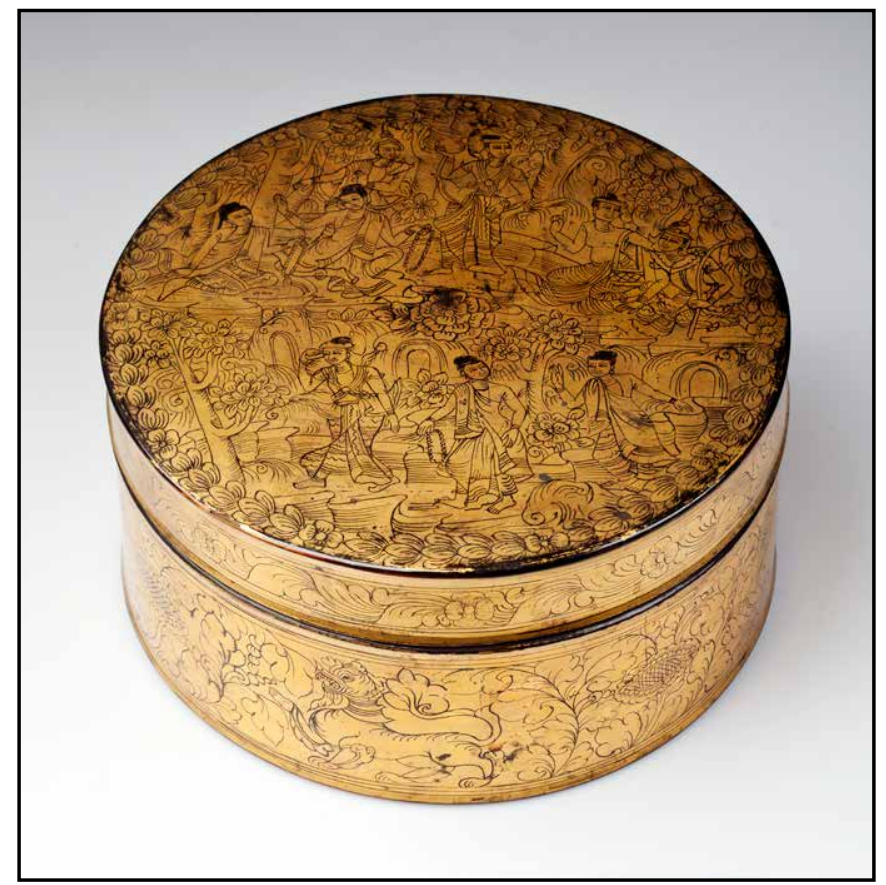

Pl. 15. Lacquer betel box, kun it. Bagan, 1960s. Dimensions: h. $10.6 \mathrm{~cm}$, diameter $21.3 \mathrm{~cm}$. Given by Otakar Pertold, 1962. Inv. No. A1173 (Photo: J. Vaněk, 2020).

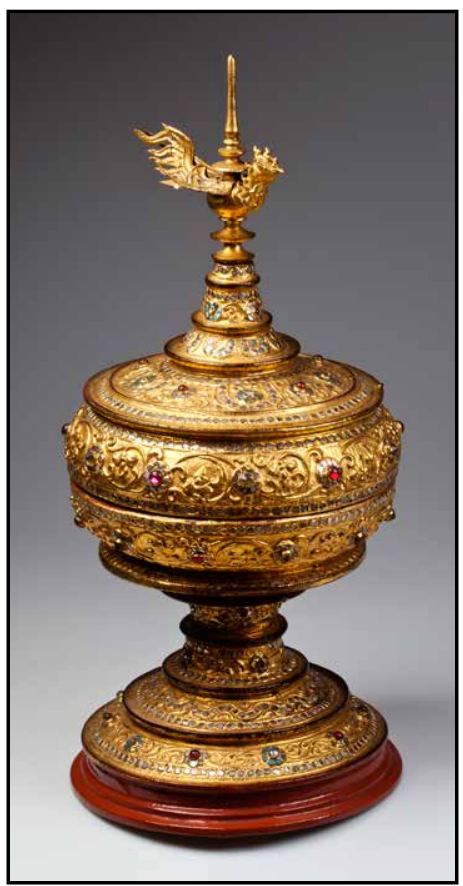

Pl. 16. Lacquered offering vessel, hsun ok. Probably Mandalay, 1960s. Dimensions: h. $56.5 \mathrm{~cm}$. Bought from the Antique Shop, 1973. Inv. No. A11347 (Photo: J. Vaněk, 2020). 


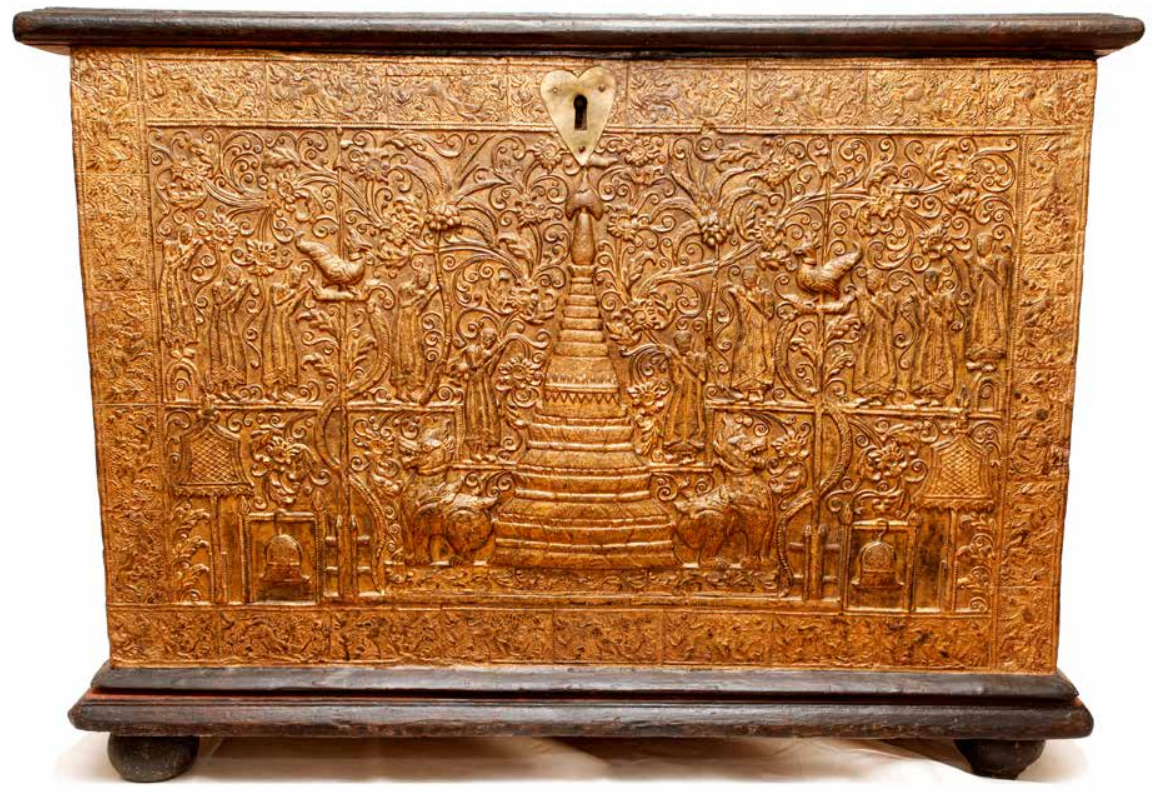

Pl. 17. Manuscript chest, sadaik, with lacquer decoration. Burma, $19^{\text {th }}$ century.

Dimensions: h. 60.5 cm, w. 82 cm, d. 61.5 cm. Origin unknown. Inv. No. 48841 (Photo: J. Vaněk, 2020).

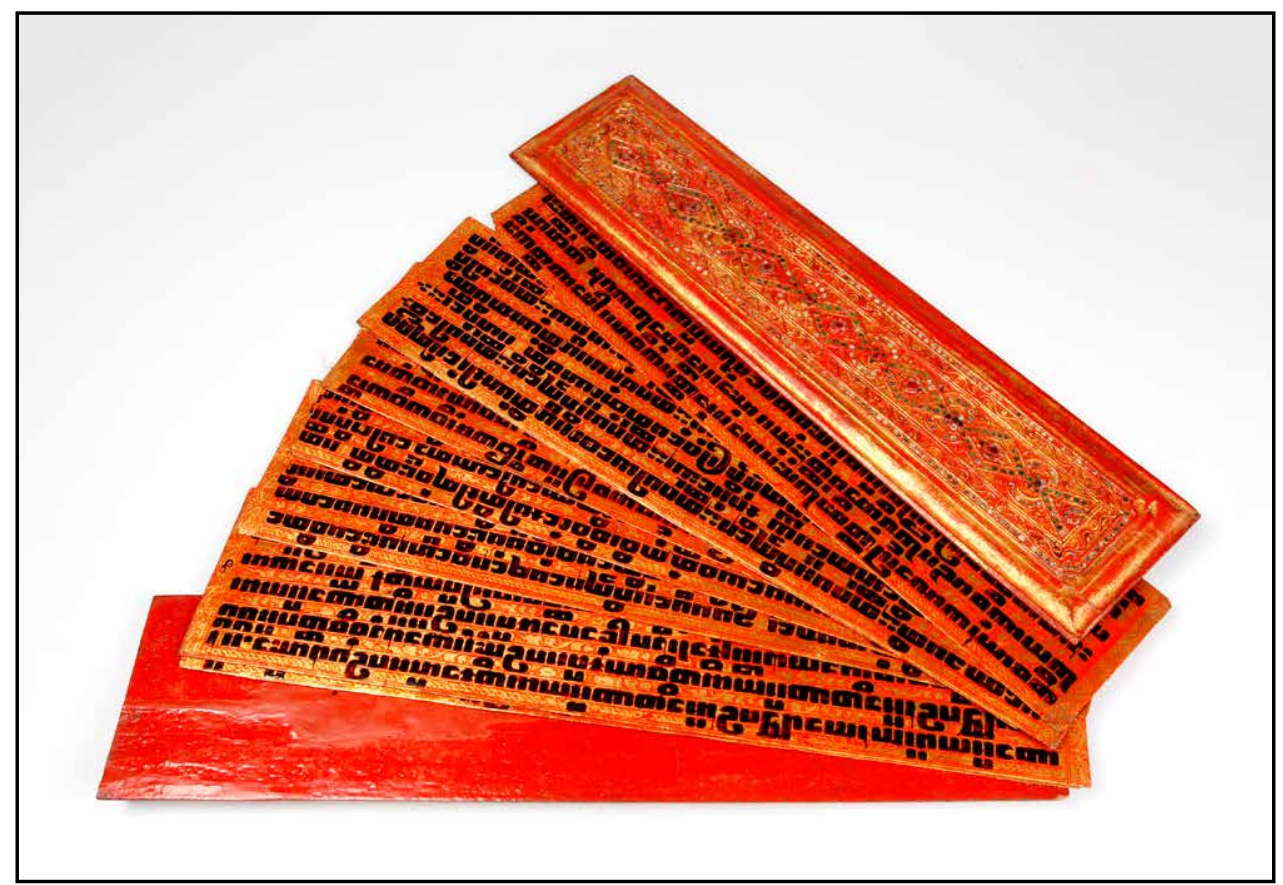

Pl. 18. Kammavaca palm leaf manuscript. Burma, around 1950. Dimensions: w. 52.5 cm, h. $12.3 \mathrm{~cm}$. Bought from Jiří Skřivánek, 1968. Inv. No. A8977 (Photo: J. Vaněk, 2020). 


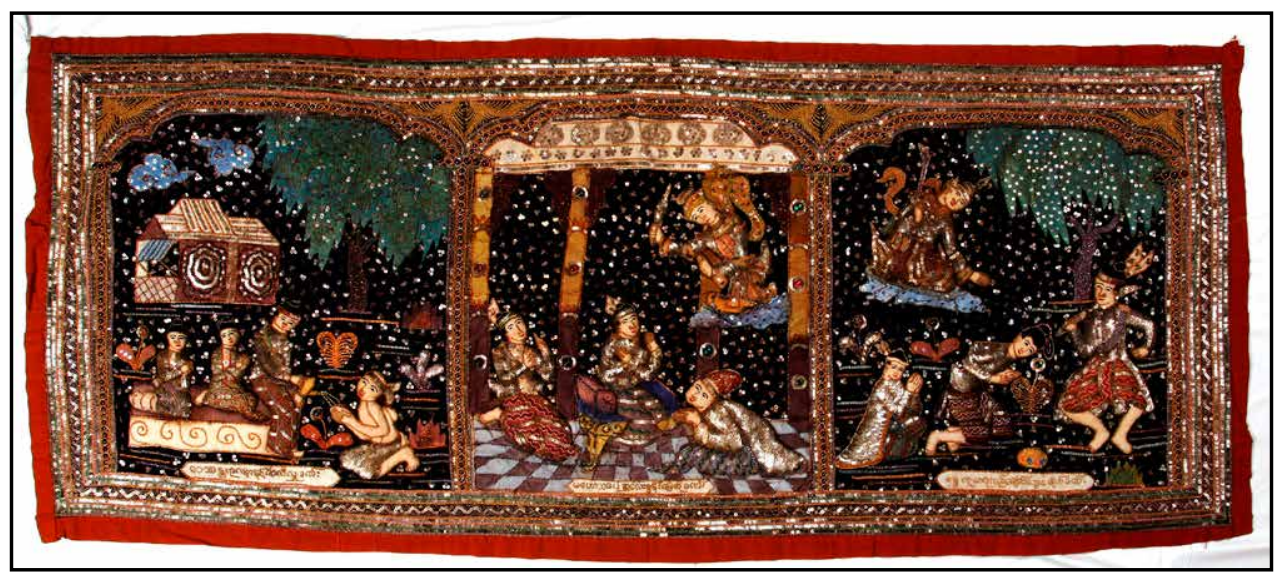

Pl. 19. Embroidered kalaga panel. Burma, 1960s. Dimensions: w. $166.5 \mathrm{~cm}, \mathrm{~h} .70 \mathrm{~cm}$. Bought from the Antique Shop, 1987. Inv. No. A17559 (Photo: J. Vaněk, 2020).

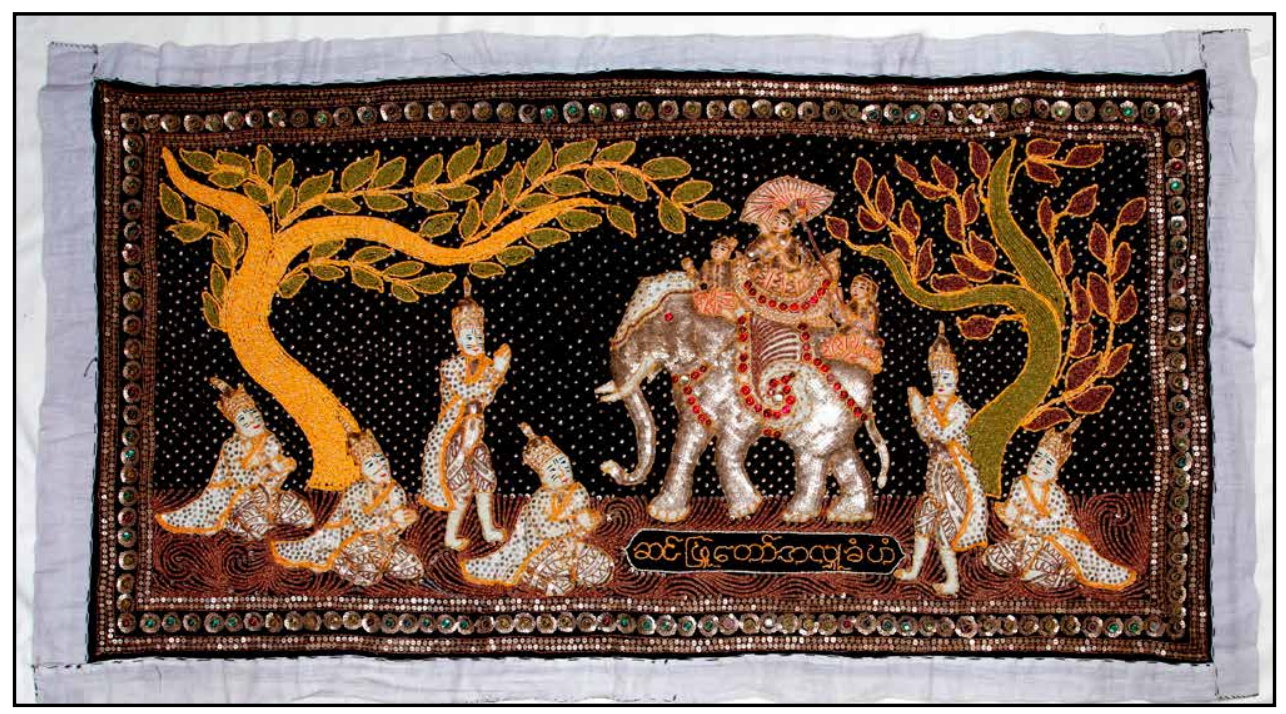

Pl. 20. Embroidered kalaga panel. Burma, 1960s. Dimensions: w. $140 \mathrm{~cm}, \mathrm{~h} .75 \mathrm{~cm}$. Bought from a private individual, 1987. Inv. No. A17665 (Photo: J. Vaněk, 2020). 